\title{
Arthropods as Vector of Plant Pathogens viz-a-viz their Management
}

\author{
Ravinder Singh Chandi, Sanjeev Kumar Kataria* and Jaswinder Kaur \\ Department of Entomology, Punjab Agricultural University, Ludhiana-141 004, Punjab, India \\ *Corresponding author
}

\begin{tabular}{|l|}
\hline Key w or d s \\
Insect vectors, Plant \\
pathogens, \\
Management
\end{tabular}

\section{A B S T R A C T}

An insect which acquires the disease causing organism by feeding on the diseased plant or by contact and transmit them to healthy plants are known as insect vectors of plant diseases. Most of the insect vectors belong to the order Hemiptera, Thysonaptera, Coleoptera, Orthoptera and Dermaptera. Homopteran insects alone are known to transmit about 90 per cent of the plant diseases. About 94 per cent of animals known to transmit plant viruses are arthropods. On the basis of the method of transmission and persistence in the vector, viruses may be classified into three categories viz. non-persistent, semi persistent and persistent viruses. Irrespective of the type of transmission, virus-vector relationship is highly specific and spread of vector borne diseases also depends upon potential of vector to spread the disease. Also for transmission of virus, activity of insect vectors is more important rather than their number. There is a high degree of specificity of phytoplasma to insects and interaction between these two is complex and variable. A number of plant diseases caused by bacteria are known to be transmitted by insects because many of these insects are actually attracted by the sugars contained in the bacterial exudates. There are several insects associated with the spread of fungal diseases. The common sooty mold fungus grows on the honeydews excreted by several homopteran insects. For the management of various types of plant diseases transmitted by insects, integrated management strategies need to be adopted to manage the vectors.

\section{Introduction}

Vector is the most important component of virus disease epiphytology. A vector is an organism capable of transmitting pathogens from one host to another. It helps in spread of virus from infected plant to the healthy plant. Plant viruses can produce direct and plantmediated indirect effects on their insect vectors, modifying their life cycle, fitness and behavior (Delafuente et al., 2013). All those insects which acquires the disease causing organism by feeding on the diseased plant or by contact and transmit them to healthy plants are known as insect vectors of plant diseases. Insect vectors include mainly aphids, leafhoppers, whiteflies, thrips, psyllids, beetles, mealybugs etc.

Plant pathogens are transmitted by a number of ways like by contact, by contamination through soil or other biological agencies. Most of the plant diseases are transmitted by insects and arthropods like mites and few of them are transmitted by mechanical means or contamination of the soil. Insects damage 
plants in many ways, but the most common type of damage is the removal of plant tissues, as in the familiar examples of caterpillars, beetles, and grasshoppers whose feeding creates noticeable holes or even the wholesale removal of leaves, fruits, or other plant parts. Insect having piercing and sucking mouthparts and biting and chewing mouthparts are associated with disease transmission. Fereres and Moreno (2009) reported that most of the plant viruses are transmitted by insect vectors, thus depend on their behavior, transmission and dispersal capacity to move from plant to plant and to spread to distantly-located regions. Hemipterans, (aphids, whiteflies and hoppers), involve most of the phytopathogenic virus vectors. Transmission of plant viruses is mediated by the piercing-sucking mouthparts of these insects (stylets), when penetrate through the intercellular spaces and establish feeding sites in phloem sieve elements (Forbes, 1969).

Most of the insect vectors belongs to the order Hemiptera (aphids, leafhoppers, whiteflies and mealybug), but a few others belong to Thysanoptera (thrips), Coleoptera (beetles), Orthoptera (grasshoppers) and Dermaptera (earwigs). Homopteran insects alone are known to transmit about 90 per cent of the plant diseases. A number of plant disease caused by viruses, phytoplamas, bacteria and fungi are transmitted by insects. The salient features of homopterans (aphids, leafhoppers) which make them efficient vectors are as follows:

They make brief but frequent probes with their mouthparts into host.

As the population density reaches a critical level, winged migratory individuals are produced.

In many species, winged females deposit a few progeny on each of the many plants.
These insects do not cause wholesome destruction of cells during feeding and viruses require living cells for their subsistence and multiplication.

\section{Viruses}

A virus is infective agent that typically consists of a nucleic acid molecule in a protein coat, is too small to be seen by light microscopy, and is able to multiply only within the living cells. Viruses are responsible for many diseases in man (influenza, measles, mumps, polio, pox, etc.) and plants (mosaic, leaf curl, etc). Plant viruses are minute parasitic which infect plant cells, altering their chemistry and causing a wide range of symptoms including discolouration, distortion and loss of vigour and yield. Plant virus diseases have become more prevalent and destructive in recent years. This is mainly because of better recognition of the virus diseases, exchange of plant material from region to region facilitating spread of the virus to new areas, and distribution of many insect vectors in new regions in the world.

Phytotoxemia is a disease like plant condition produced by toxic substance injected by insect. It is the production of plant symptoms of distress caused by the reaction of plant to the toxins produced by insect feeding. The feeding of insects and mites especially those that suck sap from the plant can cause symptom of distress such as yellowing, silvering, bronzing, necrosis, wilting and discolouration of the shoots and malformation of leaves, stem, roots, fruit and other plant organ or tissues.

The great majority of insect species responsible for phytotoxic effect on plants belong to Hemiptera. Some mites are also responsible for the phytotoxaemia and some gall forming insects are also found in other insect order. 
About 94 per cent of animals are known to transmit plant viruses are arthropods and 6 per cent are nematodes. Nearly 99 per cent of the arthropods vectors are insects and 55 per cent of these are aphids. Most of the insect vectors (90\%) belong to the order Homoptera and about half of the insect vectors are aphids. The main aphid vectors are Myzus persicae (Sulzer), Aphis gossypii Glover and Aphis craccivora Koch. In addition, whiteflies and leafhoppers are also responsible for transmission of plant viruses. Whiteflies mostly transmit mosaics and leaf curls in pulses, vegetables and other crops like cotton, tobacco and papaya (Table 1).

The leaf and plant hoppers transmit tungro, yellow-orange leaf, grassy leaf, grassy stunt and ragged stunt in rice. Tomato spotted wilt is known to be transmitted by thrips. Mandibulate insects like grasshoppers, earwigs and chrysomelid beetles transmit turnip yellow mosaic. Several species of mites are also responsible for transmission of viruses of cereals and fruit crops (Table 2). There are thousands of species of mites and spider. The mites are small arthropods, which can be red, green brown or cream in colour.

They live in associations, typically on the lower side of leaves. Spider mites can replicate speedily in hot and dry climate. After mating, females continuously produce as many as 300 eggs completed in a twosome of weeks. Mites can overwinter in more than a few stages of development, like as eggs deposited near dormant buds and as adult females under rough bark scales or ground litter (Sarwar, 2014). Fascinatingly, high humidity can really decrease mite numbers.

The wheat curl mite, which is an eriophyid, has been incriminated as the vector of two viruses of wheat. Other species are also known to transmit at least 10 other disease-causing plant pathogens. The maple bladder gall mite produces one of the most commonly seen galls found on the leaves of silver maple; this condition has attracted particular attention because of the conspicuous galls and the wide distribution of the host plant in the various states. The eruptions on the upper leaf surface are initially green, later on becoming tinted with pink and red colour (Drake et al., 2005).

Wheat streak mosaic virus (Family: Potyviridae; Genus: Tritimovirus) is a virus vectored by wheat curl mite (A. tosichella), which is the most common virus infecting wheat. The spider mite $T$. urticae is a parenchym cell content feeder; the species pierces parenchym cells and consumes their contents, producing significant leaf damage (Kant et al., 2008). The Aceria mangiferae (Family: Eriophyidae) produces distortion, stunting and bud proliferation of new growth on plants, and the mites may transmit mango malformation disease (Gamliel et al., 2009).

\section{Types of viruses}

The transmission process of vector-borne viruses is categorized by two features: (1) the time period required by the vector for acquisition of the virus and inoculation of the virus, and (2) the retention time of viral particles in the vector ( $\mathrm{Ng}$ and Falk, 2006). On this Basis, virus-vector relationships can be categorized as non-persistent, semi-persistent, or persistent. For non-persistent viruses, transmission can occur within minutes of acquiring the viral particles (virions) and particles are retained in the stylet or in the alimentary canal of the insect $(\mathrm{Ng}$ and Falk, 2006; Uzest et al., 2007; Whitfield et al., 2015). Viral particles can be lost quickly in this transmission mode and multiple encounters with infected plants are required for vectors to remain viruliferous $(\mathrm{Ng}$ and Falk, 2006). Viruses can be of nonpersistence, semi persistence and persistence type. 


\section{Non persistent viruses}

These viruses are also called stylet borne viruses. These are those viruses which are believed to be transmitted as contaminants of the mouthparts. The method of transmission of this kind of viruses is mechanical. Acquisition feeding time is very short, test feeding period is very short and virus do not multiply in the vector is a true about non-persistence transmission of virus.

These viruses do not persist longer within the insect vectors which can transmit them soon after feeding on infected plant but the ability to transmit fresh infection soon disappear after the insect feeds on healthy or immune plants e.g. mosaic-type diseases. Cucumovirus, carlaviruses and potyviruses are aphid borne stylet borne viruses. Aphids are the vectors of a great majority of such viruses which are carried only in their stylets. Following are the main features of the non-persistence viruses:

Vectors are optimally infective when they have fed for approximately 30 seconds on the infected plant.

Transmission is improved if vector is starved for a period before an infective feed.

If the vector is starved after an acquisition, it loses ability to transmit within 2 minutes.

\section{Semi-persistence viruses}

These viruses are carried in the anterior regions of the gut of a vector, where they may multiply to a certain extent. Vectors do not normally remain infective after a molt, presumably because the viruses are lost when the foregut intima is shed. Several of the leafhopper transmitted viruses fall under this category e.g. mosaic and yellows type diseases. Beet yellows virus is transmitted by aphids, A. craccivora.

\section{Persistence viruses}

Persistent viruses are those that persist longer within the infective agent. i.e. vector. These viruses, when acquired by a vector, pass through the midgut wall to the salivary glands from where they can infect new hosts. In case of these viruses, insect feeds for longer time on the source of virus.

The insect becomes infective after a certain period of acquisition of virus ranging from several hours to 10-20 days, which is called incubation period or latent period.

Such viruses may multiply within tissues of a vector, which retains the ability to transmit the virus for several days and in some instances, the rest of its life e.g. virus transmitted by whitefly is persistent and circulative type.

\section{Mechanism of transmission}

For inoculation of virus into a plant by sucking insects, the puncture is transmitted by a number of forward and backward movements of the inner pair of stylets. Fluid flows into them with forward movements and saliva ejected during backward movements.

Generally, an insect injects by feeding on any part of the plant, but in some cases the virus is only found in the phloem and has to be injected into the phloem, the movement of which is perhaps controlled by the $\mathrm{pH}$ gradient between the mesophyll and the phloem. Many insects facilitate the entry of a pathogen into its host through the wounds and insects make holes in aboveground and belowground parts of the plants (Agrios, 1997).

Grasshoppers and beetles insects regurgitate with mandibulate during feeding. The regurgitated fluid containing the virus is brought into contact with the healthy plant, thus transmitting the virus. 


\section{Virus-vector relationship}

Irrespective of the type of transmission, virusvector relationship is highly specific. Generally one type of virus disease is transmitted only by insects belongings to one particular group, i.e. mosaic by aphids and leaf curl by whitefly. Single virus can be transmitted by more vectors. This depends upon the specificity of vector, for example cucumber mosaic virus is transmitted by 2 vectors i.e $M$. persicae and A. gossypii. Sometimes one vector can transmit more than one virus. $M$. persicae can transmit different viruses like potato leaf roll virus, potato virus Y. The capability of vector to transmit the virus is an important step to know its potential, as different vectors transmit the viruses in variable proportion.

\section{Vector population and activity}

The vector density must be affecting the virus spread by influencing vector movement and associated activity. The understanding of vector abundance and vector movement is very important before monitoring of population density. Vector population depends on environment factors, host type and growth stage.

\section{Host seeking activity}

Without host seeking activity by the vector, the virus cannot be carried to potential non infected host plant. Host seeking activity is very helpful in the transmission of virus. Host seeking activity involves finding a suitable host plant, landing on the host plant and probing the plant by feeding on parenchyma tissue. All the plant cells have a robust cell wall and viruses cannot penetrate them unaided. Mostly plant viruses are therefore transmitted by a vector organism that feeds on the plant or (in some diseases) are introduced through wounds made during pruning. A small number of viruses can be transmitted through pollen to the seed (e.g. Barley stripe mosaic virus, genus Hordeivirus) while many that cause systemic infections accumulate in vegetatively propagated crops. Aphids transmit viruses from many different genera, including Potyvirus, Cucumovirus and Luteovirus with the help of green peach aphid M. persicae, the vector of many plant viruses, including Potato virus Y. The aphids, Pentalonia nigronervosa Conquerel, transmit banana bunchy top and cardamom mosaic. Similarly, the whiteflies transmit viruses from several genera like okra yellow vein mosaic, dolichos yellow mosaic, tomato leaf curl, papaya leaf curl, but particularly those in the genus Begomovirus. B. tabaci, the vector of many viruses including tomato yellow leaf curl virus and lettuce infectious yellows virus. The hoppers transmit viruses from several genera, including those in the families Rhabdoviridae and Reoviridae. Thrips transmit viruses in the genus Tospovirus and Frankinella occidentalis, the western flower thrips that is a major vector of Tomato spotted wilt virus. For transmission of virus, activity of insect vectors is more important rather than their number. In case of aphids, it is the activity and number of migrant insects that is important in the efficiency of virus transmission rather than the number of apterous individuals which are, of course, important in respect of their direct injury to the crop.

\section{Aphids}

The majority of viruses infecting plants are spread by insects, and aphids are the most common group of virus vectors or carriers. All potyviruses (the largest group of plant viruses) are transmitted by aphids. Aphids are sapsucking insects and have piercing, sucking mouthparts. Their mouthparts include a needle-like stylet that allows the aphid to access and feed on the contents of plant cells. 
During feeding, aphids simultaneously ingest sap contents and inject saliva, which can contain viruses if the aphid has previously fed on an infected plant. Transmission of a virus by insects is a specific biological process. A particular virus is transmitted by one carrier group only for example aphids or whiteflies, not both. The two broad categories of aphid transmission are: non-persistent and persistent or circulative. These terms relate to the length of time an aphid takes to acquire and then transmit a virus, and the length of time the aphid remains capable of transmitting the virus.

Plant viruses may also interact directly with their insect vectors, altering their behavior to enhance their own spread. Recently, Stafford et al., (2011) found that tomato spotted wilt virus (TSWV) directly modifies the feeding behavior of its vector Frankliniella occidentalis increasing its ability to transmit the virus. Ingwell et al., (2012) found that after acquisition of barley yellow dwarf viruses (BYDVs) the settling behavior of aphid Rhopalosiphum padi changed. Aphids that acquired the virus preferred to feed on non-infected wheat plants, while non-infective aphids preferred BYDV infected plants.

BYDVs are economically important viruses that infect cereal crops worldwide, including wheat grown in China. These viruses are transmitted only by aphids and include several members of the luteoviridae (Du et al., 2007). BYDVs are naturally transmitted by at least 25 aphid species in a highly specific, circulative, non-propagative manner, and have been found infecting agronomically important small grains (Gray and Gildow, 2003). Another virus-vector mutualism relationship was found when the aphid Sitobion avenae, fed on BYDV infected wheat (Fereres et al., 1989). Aphids had a significantly shorter developmental time, a greater fecundity, and a greater intrinsic rate of natural increase on
BYDV infected than on non-infected plants. Conversely, the infection of soybean with alfalfa mosaic, soybean mosaic and bean pod mottle viruses, inoculated separately, had several negative effects in the aphid Aphis glycines performance, decreasing the aphid population growth rate and the aphid density on infected plants (Donaldson and Gratton, 2007).

Cucumber mosaic virus (CMV) is one of the most common virus pathogens of plants, and infects over 1,000 species (Roossinck, 2002). The genus of CMV is cucumovirus in the family bromoviridae (Palulaitis et al., 1992), is a multicomponent virus consisting of three genomic single-stranded RNA's each encapsidated individually in a $28 \mathrm{~nm}$ diameter icosahedral particle. CMV is aphid transmitted in a stylet-borne non-persistent manner (Nault, 1997). The components of the aphid stylet interact directly with virus capsid protein to influence transmission efficiency (Chen and Francki, 1990 and Perry et al., 1998), and do not utilize a virus encoded helper component protein, as do non-persistently transmitted potyviruses.

Most CMV strains are currently divided between two major groups (subgroup 1 and subgroup 2) based on serological and sequence similarities (Andersom et al., 1995, Hsu et al., 2000). Common strains of CMV typically infect solanaceous and cucurbit crops, but not legume species. Legumeinfecting strains of CMV isolated from infected peas were first described by Whipple and Walker (1941). These strains were not seed transmitted, but were transmissible by the green peach aphid.

\section{Whitefly}

Whitefly, Bemisia tabaci (Hemiptera: Aleyrodidae) a complex of morphologically indistinguishable species, are vectors of many 
plant viruses (Polston and Capobianco, 2013). Whitefly transmitted plant viruses included several genera (Begomovirus, Carlavirus, Crinivirus, Ipomovirus, and Torradovirus) and also include several hundred species of emerging and economically significant pathogens of important food and fiber crops. These viruses do not replicate in their vector but move readily from plant to plant by the adult whitefly by various means. For most of these viruses whitefly feeding is required for acquisition and inoculation, while for others only probing is required.

Navas et al., (2011) found that most of the begomoviruses (Family: Geminiviridae) are transmitted by whiteflies, although these are also vectors of criniviruses, ipomoviruses, torradoviruses and some carlaviruses. Rosen $e t$ al., (2015) studied that the begomoviruses comprise an emerging and economically important group of plant viruses exclusively transmitted by the $B$. tabaci in many regions of the world. Begomoviruses is one of the largest and economically important group of emerging insect vector. Begomoviruses are exclusively vectored by $B$. tabaci in a persistent circulative manner.

Moreno-Delafuente et al., (2013) studied that B. tabaci female adults were subjected to an acquisition access period of $72 \mathrm{~h}$ in tomato yellow leaf curl virus (TYLCV) infected and non-infected tomato plants to obtain viruliferous and non-viruliferous whiteflies, respectively. The results show evidence that TYLCV directly manipulates the settling, probing and feeding behavior of its vector $B$. tabaci in a way that enhances virus transmission efficiency and spread. Furthermore, TYLCV and B. tabaci interactions are mutually beneficial to both the virus and its vector because $B$. tabaci feeds more efficiently after acquisition of TYLCV. This outcome has clear implications in the epidemiology and management of the
TYLCV-B. tabaci complex.

B. tabaci is a destructive pest of horticultural crops and ornamental plants worldwide (Brown et al., 1995 and Dalton, 2006) especially because of its role as a vector of plant viruses (Brown and Czosnek, 2002) and (Hogenhout et al., 2008). Actually, B. tabaci is a species complex containing at least 28 morphologically indistinguishable species (De Barro et al., 2011 and Liu et al., 2012). Among these, the 'Mediterranean' putative species (Liu et al., 2012 and Sun et al., 2011) has been previously referred as the $\mathrm{Q}$ biotype and is the most extended in Spain.

Mutualism relationships between plant viruses and their insect vectors have been observed in some Hemipterans. In the case of $B$. tabaci biotype $\mathrm{B}$ and tomato yellow leaf curl China virus (TYLCCNV) interactions, Jiu et al., (2007) found that fecundity, longevity and population density of whiteflies on virusinfected tobacco plants increased. Zhang et al., (2012) explained that this mutualism is a consequence of changes in plant defense responses after begomovirus infection. In fact, the infection by TYLCCNV interferes with the synthesis of jasmonic acid that is utilized by plants against herbivory attack, resulting in enhanced performance of B. tabaci. Furthermore, Luan et al., (2012) found that plant defensive compounds named terpenoids, were depleted by begomovirus infection, favoring whitefly fitness.

TYLCV, as other geminivirus, has some pathogenic characteristics and could be deleterious to its vector, B. tabaci. In fact, the presence of TYLCVs in B. tabaci has been associated with a decrease in the insect longevity and fertility (Jiu et al., 2007, Rubinstein and Czosnek, 1997, Pusag et al., 2012). Furthermore, a recent study demonstrated an imbalanced nutrition of whiteflies infected with TYLCCNV (Wang et 
al., 2012). However, limited studies of changes in the behavior of whiteflies due to infection with plant viruses such as TYLCVs have been reported.

\section{Phytoplasmas}

Phytoplasmas (originally called mycoplasmalike organisms) are non-cellular degenerate gram-positive prokaryotes closely related to mycoplasmas and spiroplasmas. The phytolasmas are non culturable parasitic prokaryotes, the mechanism of dissemination is mainly by insect vectors.

The common vectors or at least those best known are members of the order Hemiptera, from the families Cicadellidae, Cixiidae, Psyllidae, Cercopidae, Delphacidae, Derbidae, Menoplidae and Flatidae. In the majority of cases transmission is only transovarial and has only been demonstrated in a few species (Beanland et al., 2000 and Hanboonsong et al., 2002).

Insect vectors primarily leafhoppers, planthoppers and psyllids, have been identified for relatively few phytoplasm diseases (Weintraub and Beanland, 2006). To be transmitted to plant, phytoplasmas must penetrate and accumulate at high levels in the acinar cells posterior o the salivary glands.

In the salivary glands there are three barriers that the pathogens must overcome before they can be expelled with the saliva: the basal lamina, the basal plasmalemma and the apical plasmalemma. This group collectively possesses several characteristics that make its members efficient vectors of phytoplasmas.

They are hemimetabolous, thus nymphs and adults feed similarly and are in the same physical location-often both immature and adults can transmit phytoplasmas.
They feed specifically and selectivity on certain plant tissues, which makes them efficient vectors of pathogens residing in these tissues.

Their feeding is nondestructive, promoting successful inoculation of the plant vascular system without damaging the conductive tissues and eliciting defensive responses.

They have a prokaryotic and persistent relationship with phytoplasmas. They have obligate symbiotic prokaryotes that are passed to be offspring by transovarial transmission, the same mechanism that allow the transovarial transmission of phytoplasmas

\section{Mechanism of transmission}

Phytoplasmas are important phloem limited, insect transmitted pathogenic agents causing a thousand diseases, many of which are lethal, in hundreds of plant species (Weintraub, 2007). Only phloem feeding insects can potentially acquire and transmit the pathogen.

The single most successful order of insect phytoplasmas vectors is the Auchenorrhyncha. They are efficient vectors of phytoplasmas because nymphs and adults feed similarly and are in the same physical location, often, similarly and are in the same physical location, both immature and adults can transmit phytoplasmas are propagative and persistent in them.

Most phytoplasma vectors are members of the family Cicadellidae like brinjal little leaf, apple proliferation, aster yellows, tomato big bud and pear decline (Table 3).

The feeding duration necessary to acquire a sufficient titer of phytoplasm (acquisition access period), may range from a few minutes to several hours, the longer the period, the greater the chance of acquisition. 
Table.1 List of important insect vectors of plant viruses

\begin{tabular}{|c|c|c|}
\hline \begin{tabular}{c|} 
S. \\
No.
\end{tabular} & Insect vector & Virus (Hosts) \\
\hline 1. & $\begin{array}{l}\text { Acyrthosiphon pisum (Harris) } \\
\text { (Hemiptera: Aphididae) }\end{array}$ & $\begin{array}{l}\text { Alfalfa mosaic (alfalfa), bean mosaic (beans), onion } \\
\text { yellow dwarf (onion), pea mosaic (peas), soybean } \\
\text { mosaic (beans, peas) }\end{array}$ \\
\hline 2. & $\begin{array}{l}\text { Aphis craccivora Koch } \\
\text { (Hemiptera: Aphididae) }\end{array}$ & $\begin{array}{l}\text { Alfalfa mosaic (alfalfa), cowpea mosaic (cowpea), } \\
\text { onion yellow dwarf (onion), papaya mosaic (papaya) }\end{array}$ \\
\hline 3. & $\begin{array}{l}\text { Aphis gossypii Glover } \\
\text { (Hemiptera: Aphididae) }\end{array}$ & $\begin{array}{l}\text { Alfalfa mosaic (alfalfa, potato), chilli mosaic (chillies), } \\
\text { cucumber mosaic (cucumber), dahlia mosaic (dahlia, } \\
\text { zinnia) lettuce mosaic (lettuce, sweet pea), papaya } \\
\text { mosaic (papaya), sugarcane mosaic (sugarcane) }\end{array}$ \\
\hline 4. & $\begin{array}{l}\text { Bemisia tabaci (Gennadius) } \\
\text { (Hemiptera: Aleyrodidae) }\end{array}$ & $\begin{array}{l}\text { Cotton leaf curl (cotton), dolichos yellow mosaic } \\
\text { (dolichos), okra yellow vein mosaic (okra), papaya leaf } \\
\text { curl (papaya), sesame leaf curl (sesame), tobacco leaf } \\
\text { curl (tobacco), tomato leaf curl (tomato) }\end{array}$ \\
\hline 5. & $\begin{array}{l}\text { Laodelphax striatella Fallen } \\
\text { (Hemiptera: Delphacidae) }\end{array}$ & Rice streaked dwarf (rice), rice stripe (rice) \\
\hline 6. & $\begin{array}{l}\text { Myzus persicae (Sulzer) } \\
\text { (Hemiptera: Aphididae) }\end{array}$ & $\begin{array}{l}\text { Alfalfa mosaic (alfalfa), beet yellows (spinach, } \\
\text { sugarbeet), cabbage black ring spot (cabbage), } \\
\text { cauliflower mosaic (cabbage, cauliflower), cucumber } \\
\text { mosaic (cucumber), dahlia mosaic (calendula, dahlia, } \\
\text { zinnia), lettuce mosaic (garden pea, lettuce, sweet pea), } \\
\text { onion yellow dwarf (onion), pea mosaic (broadbean, } \\
\text { garden pea, sweet pea), potato virus Y (potato, tobacco, } \\
\text { tomato), soybean mosaic (soybean), sugarcane mosaic } \\
\text { (maize, sorghum, sugarcane) }\end{array}$ \\
\hline 7. & $\begin{array}{l}\text { Nephotettix nigropictus (Stal), } \\
\text { N. virescens } \text { (Distant) } \\
\text { (Hemiptera: Cicadellidae }\end{array}$ & Tungro (rice), yellow-orange leaf (rice) \\
\hline 8. & $\begin{array}{l}\text { Nilaparvata lugens }(\text { Stal) } \\
\text { (Hemiptera: Delphacidae) }\end{array}$ & Grassy stunt (rice), ragged stunt (rice) \\
\hline 9. & $\begin{array}{l}\text { Pentalonia nigronervosa Coquerel } \\
\text { (Hemiptera: Aphididae) }\end{array}$ & $\begin{array}{l}\text { Banana bunchy top (banana), cardamom mosaic } \\
\text { (cardamom) }\end{array}$ \\
\hline 10. & $\begin{array}{l}\text { Rhopalosiphum maidis (Fitch) } \\
\text { (Hemiptera: Aphididae) }\end{array}$ & $\begin{array}{l}\text { Barley yellow dwarf (barley, oat, rye, wheat), onion } \\
\text { yellow dwarf (onion), sugarcane mosaic (maize, } \\
\text { sorghum, sugarcane) }\end{array}$ \\
\hline
\end{tabular}

Source: Modified after Gillot, 2005 
Table.2 List of important mite vectors of virus diseases of plants

\begin{tabular}{|c|c|c|c|}
\hline Sr. No. & Mite vector & Virus & Host(s) \\
\hline 1 & $\begin{array}{l}\text { Abbacarus hystrix (Nalepa) } \\
\text { (Acari: Eriophyidae) }\end{array}$ & Agropyron mosaic & Wheat, switch grass \\
\hline 2 & $\begin{array}{l}\text { Aceria ficus (Corte) (Acari: } \\
\text { Eriophyidae) }\end{array}$ & Fig mosaic & Fig \\
\hline 3 & $\begin{array}{l}\text { Aceria tulipae (Keifer) (Acari: } \\
\text { Eriophyidae) }\end{array}$ & Wheat streak mosaic & Wheat, oats, barley, maize \\
\hline 4 & $\begin{array}{l}\text { Aculus fockeui (Nalepa and } \\
\text { Trouessart) (Acari: Eriophyidae) }\end{array}$ & Prunus necrotic ring spot & Plum, peach, cherry \\
\hline 5 & $\begin{array}{l}\text { Eriophyes inaequalis Wilson and } \\
\text { Oldfield (Acari: Eriophyidae) }\end{array}$ & Cherry leaf mottle & Sweet cherry \\
\hline 6 & $\begin{array}{l}\text { Eriophyesinsidiosu Keifer and } \\
\text { Wilson (Acari: Eriophyidae) }\end{array}$ & Peach mosaic & Peach, nectarine \\
\hline
\end{tabular}

Source: Modified after Gillot, 2005

Table.3 List of important vectors of phytoplasma-transmitted diseases

\begin{tabular}{|c|c|c|c|c|}
\hline Sr. No. & Insect Vector & Mycoplasma(s) & Host(s) & References \\
\hline 1 & Circulifer tenellus (Baker) & $\begin{array}{l}\text { Columbia basin } \\
\text { potato purple top }\end{array}$ & Beet, potato, weeds & $\begin{array}{l}\text { Munyaneza et al., } \\
2007\end{array}$ \\
\hline 2 & $\begin{array}{l}\text { Cestius } \quad \text { phycitis } \\
\text { (Hempitera: } \text { Cicadellidae) }\end{array}$ & Brinjal little leaf & Brinjal & Gillot, 2005 \\
\hline 3 & Fieberiella florii Stal & $\begin{array}{l}\text { Apple } \\
\text { proliferation }\end{array}$ & Apple proliferation/16SrZ-A & $\begin{array}{l}\text { Tedeschi and Alma, } \\
2006\end{array}$ \\
\hline 4 & Macrosteles sp. & Lettuce & 16SrI-B group & Borth et al., 2006 \\
\hline 5 & $\begin{array}{l}\text { Nephotettix } \begin{array}{l}\text { nigropictus } \\
\text { virescens }\end{array} \text { (Distant) } N . \quad \text { (Hemiptera: } \\
\text { Cicadellidae) }\end{array}$ & Yellow dwarf & Rice & Gillot, 2005 \\
\hline 6 & $\begin{array}{l}\text { Macrosteles quadrillineatus Forbes } \\
\text { (Hemiptera: Cicadellidae) }\end{array}$ & Aster yellows & $\begin{array}{l}\text { Aster, barley, carrot, celery, } \\
\text { cucumber, wheat, rice }\end{array}$ & Gillot, 2005 \\
\hline 7 & $\begin{array}{l}\text { Neoaliturus fenestratus (Herrich- } \\
\text { Schaffer) }\end{array}$ & Lettuce phyllody & Lettuce, wild lettuce & Salehi et al., 2006 \\
\hline 8 & Orosius orentalis (Matsumura) & $\begin{array}{l}\text { Garden beet } \\
\text { witches' broom }\end{array}$ & Beets & Mirzaie et al., 2006 \\
\hline 9 & $\begin{array}{l}\text { Orosius albicinctus } \quad \text { (Distant) } \\
\text { (Hemiptera: Cicadellidae) }\end{array}$ & Sesame phyllody & Sesame & Gillot, 2005 \\
\hline 10 & $\begin{array}{l}\text { Recilia dorsalis (Motschulsky) } \\
\text { (Hemiptera: Cicadellidae) }\end{array}$ & Yellow dwarf & Rice & Gillot, 2005 \\
\hline 11 & $\begin{array}{l}\text { Stephanitis typical } \\
\text { (Hemiptera: Cicadellidae) }\end{array}$ & Coconut root wilt & Coconut & Gillot, 2005 \\
\hline 12. & $\begin{array}{l}\text { Aster leafhopper Macrosteles } \\
\text { fascifrons }\end{array}$ & Aster yellows & $\begin{array}{l}\text { Tomato, lettuce, carrot, onion, } \\
\text { potato, chrysanthemum, aster }\end{array}$ & Thind, 2012 \\
\hline 13. & $\begin{array}{l}\text { Brown leafhopper, Orosius } \\
\text { argentatus }\end{array}$ & Tomato big bud & $\begin{array}{l}\text { Solanaceous vegetables and } \\
\text { lettuce }\end{array}$ & Thind (2012) \\
\hline 14. & $\begin{array}{l}\text { Leafhoppers, including Philaenus } \\
\text { spumarius, Aphrophora alni, } \\
\text { Lepyronia coleoptrata, Artianus } \\
\text { interstitialis, and Fieberiella florii }\end{array}$ & $\begin{array}{l}\text { Apple } \\
\text { proliferation }\end{array}$ & $\begin{array}{l}\text { Wild and ornamental apple } \\
\text { species, and possibly pear and } \\
\text { apricot }\end{array}$ & Thind (2012) \\
\hline 15. & Pear psylla, Psylla pyricola & Pear decline & Pear & Thind, 2012 \\
\hline
\end{tabular}


Table.4 List of major vectors of bacterial diseases of crop plants

\begin{tabular}{|c|c|c|c|}
\hline S.No. & Insect vector & Disease & Host(s) \\
\hline 1. & $\begin{array}{l}\text { Seed corn maggot, Delia platura } \\
\text { (Diptera: Anthomyiidae) }\end{array}$ & $\begin{array}{l}\text { Bacterial soft rot of } \\
\text { potato }\end{array}$ & $\begin{array}{l}\text { Potato and nearly all fleshy } \\
\text { vegetables are subject to } \\
\text { bacterial soft rots. }\end{array}$ \\
\hline 2. & $\begin{array}{l}\text { Striped cucumber beetle } \\
\text { Acalymma vittatum and the } \\
\text { spotted cucumber beetle, } \\
\text { Diabrotica undecimpunctata } \\
\text { (Coleoptera: Chrysomelidae) }\end{array}$ & $\begin{array}{l}\text { Bacterial wilt of } \\
\text { cucurbits }\end{array}$ & 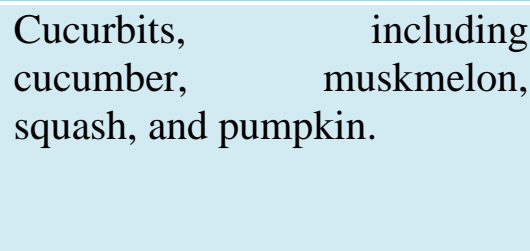 \\
\hline 3. & $\begin{array}{l}\text { Corn flea beetle, Chaetocnema } \\
\text { pulicaria } \\
\text { Chrysomelidae) }\end{array}$ & $\begin{array}{l}\text { Bacterial wilt of } \\
\text { corn }\end{array}$ & $\begin{array}{l}\text { Sweet corn, Dent corn, } \\
\text { Popcorn, Field corn, gamma } \\
\text { grass, Teosinte }\end{array}$ \\
\hline 4. & $\begin{array}{l}\text { Aphids, leafhoppers, psyllids, } \\
\text { beetles, flies, and ants (More than } \\
200 \text { species) }\end{array}$ & $\begin{array}{l}\text { Fire blight of pears, } \\
\text { apples and other } \\
\text { rosaceous plants }\end{array}$ & $\begin{array}{l}\text { Pears, apples and other } \\
\text { rosaceous plants }\end{array}$ \\
\hline 5. & $\begin{array}{l}\text { Olive fruit fly, Bactrocera oleae } \\
\text { (Diptera: Tephritidae) }\end{array}$ & Olive knot & Olive \\
\hline 6. & $\begin{array}{l}\text { Sharpshooter leafhoppers, Blue } \\
\text { green (Graphocephala } \\
\text { atropunctata), Green } \\
\text { (Draeculacephala minerva), Red } \\
\text { headed (Carneocephala fulgida), } \\
\text { Glassy winged (Homalodisca } \\
\text { coagulata) } \\
\text { (Hemiptera: Cicadellidae) }\end{array}$ & $\begin{array}{l}\text { Pierce's disease of } \\
\text { grape }\end{array}$ & $\begin{array}{l}\text { European-type grapes, } \\
\text { muscadine grapes, hybrids of } \\
\text { European grapes and } \\
\text { American wild grapes }\end{array}$ \\
\hline 7. & $\begin{array}{l}\text { Citrus psyllid, Asian pysllid i.e. } \\
\text { Diaphorina citri and African } \\
\text { psyllid i.e. Trioza erytreae. } \\
\text { (Hemiptera: Psyllidae) }\end{array}$ & $\begin{array}{l}\text { Citrus } \quad \text { greening } \\
\text { disease }\end{array}$ & Citrus \\
\hline 8. & $\begin{array}{l}\text { Leafhoppers Empoasca papayae } \\
\text { and E. stevensi (Hemiptera: } \\
\text { Cicadellidae) }\end{array}$ & $\begin{array}{l}\text { Bunchy top of } \\
\text { papaya }\end{array}$ & Papaya \\
\hline 9. & $\begin{array}{l}\text { Hylemya cilicrura (Rondani), } H . \\
\text { trichodactyla (Rondani), } \\
\text { (Diptera: Anthomyiidae) }\end{array}$ & Potato blackleg & Potato \\
\hline 10. & $\begin{array}{l}\text { Diaphorina citri Kumayama } \\
\text { (Hemiptera: Aphalaridae) }\end{array}$ & Citrus canker & Citrus \\
\hline
\end{tabular}

Source: (Gillot, 2005 and Thind, 2012) 
Table.5 List of principal vectors of fungal diseases of crop plants

\begin{tabular}{|c|c|c|c|}
\hline $\begin{array}{c}\text { Sr } \\
\text { No. }\end{array}$ & Insect vector(s) & Diseases & Host \\
\hline 1. & $\begin{array}{l}\text { Hylurgopinus rufips } \\
\text { (Coloptera: Scolytidae) }\end{array}$ & Dutch elm & Elm \\
\hline 2. & $\begin{array}{l}\text { Melanoplus differetialis (Thomas) } \\
\text { (Orthoptera: Acrididae) }\end{array}$ & Cotton wilt & Cotton \\
\hline 3. & $\begin{array}{l}\text { Several species of insect visiting } \\
\text { flowers }\end{array}$ & Ergot of bajra & Bajra \\
\hline 4. & Bees & $\begin{array}{l}\text { Blossom blight of red } \\
\text { clover }\end{array}$ & Red clover \\
\hline 5. & $\begin{array}{l}\text { Monilinia fructicola, M. fructigena, } \\
\text { and M. laxa. }\end{array}$ & $\begin{array}{l}\text { Brown rot of stone and } \\
\text { pome fruits }\end{array}$ & Stone and pome \\
\hline 6. & $\begin{array}{l}\text { Fusarium moniliforme, Alternaria } \\
\text { tenuis, Aspergillus flavus, and } \\
\text { Rhizopus nigricans }\end{array}$ & Boll rots & Cotton \\
\hline 7. & Rice stinkbug, Oebalus pugnax & Rice mold & Rice \\
\hline
\end{tabular}

Source: Dollet 2001 and Gillot 2005

The time that elapse from initial acquisition to the ability to transmit the phytoplasmas (latent period or incubation periods) is temperature dependent and ranges from a few to 80 days. Phytoplasmas during latent period moves through and replicate in the vector's body. They can pass intracellularly through the epithelial cells of the midgut and replicate within a vesicle or they can pass between two midgut cells and through the basement membrane to enter the haemocoel. Phytoplasmas circulate in the haemocoel, where they may infect other tissues such as the malpighian tubules, fat bodies and brain or reproductive organs. To be transmitted to plants, phytoplasmas must penetrate specific cells of the salivary glands and high levels must accumulate in posterior acinar cells of the salivary glands before they can be transmitted.

\section{Vector phytoplasma relationship}

The interaction between insects and phytoplasmas is complex and variable. The complex sequence of events required for an insect to acquire and subsequently transmit phytoplasmas to plants suggests a high degree of specificity of phytoplasmas to insects.

However, numerous phytoplasmas are transmitted by several different insect species. In addition, a single vector species may transmit two or more phytoplasmas, and an individual vector can be infected with dual or multiple phytoplasma strains. It has been found that leafhoppers do not acquire equally phytoplasmas from different plant species.

\section{Bacteria}

Bacteria are microscopic single celled organism that thrives in diverse environments. They can live within soil, in the ocean and inside the human gut. A number of plant diseases caused by bacteria are known to be transmitted by insects (Table 4). Bacterial wilt of corn caused by Erwinia carotovora pv. carotovora and transmitted by seed corn maggots. Potato blackleg, caused by Erwinia carotowora, is transmitted by seed corn maggot, Hylemyia cilicrura (Rondani). 
Bacterial wilt of maize, caused by Xanthomonas stewarti is transmitted by the flea beetle, Chaetocnema pulicaria (Meisheimer).

\section{Role of insects in bacterial diseases of plants}

In most plant diseases caused by plant pathogenic bacteria (especially in those that cause spots, cankers, blights, galls, soft rots) which are produced within or between plant cells, escape to the surface of their host plants as droplets or masses of sticky exudates. The bacteria exudates are released through cracks or wounds in the infected area or through natural openings such as stomata, nectarthodes, hydathodes and sometimes through lenticells present in the infected area. Such bacteria are then likely to stick on the legs and bodies of all sorts of insects such as flies, aphids, ants, beetles, whiteflies, etc. that land on the plant and come in contact with the bacterial exudates.

Many of these insects are actually attracted by the sugars contained in the bacterial exudates and feed on it, thereby further smearing their body and mouthparts with the bacteria containing exudates. When such bacteria smeared insects move to other parts of the plant or to other susceptible host plants, they carry on their body numerous bacteria. If the insects happen to land on a fresh wound or on an open natural opening, and there is enough moisture on the plant surface, the bacteria may multiply, move into the plant, and begin a new infection.

Numerous plant diseases could be listed among those in which bacteria are spread by insects passively as described above, for example, the bacterial bean blights, fire blight of apple and pear, citrus canker, cotton boll rot, crown gal, bacterial spot and canker of stone fruits, etc.

\section{Fungi}

Fungi are organism having no chlorophyll, reproducing by sexual and asexual spores, not by binary fission like bacteria and typically possessing a mycelium or mass of interwoven threads (hyphae) containing well marked nuclei. There are about 4300 valid genra of fungi and about 70000 species living as parasites or saprophytes on other organisms on their residues.

There are several insects associated with the spread of fungal disease (Table 5). The ergot disease of bajra caused by Sphacelia microcephala is mechanically carried by insects that visit the flowers attracted by the surgery secretions found on the fungus infected earheads. The common sooty mold fungus (Capnodiuim spp.) grows on the honeydews excreted by several homopteran insects like insects, leafhoppers, mealybugs, whiteflies, etc.

\section{Management of vectors and diseases}

The interactions between vectors, plant pathogens and crops are not so simple. Many pathogens may be transmitted by more than one insect vector, and on the contrary, there are some vector species that are able to transmit different plant pathogens. The knowledge about insect vectors is therefore crucial when deciding pest management strategies, especially on a wide scale area. Among the various types of plant diseases transmitted by insects, virus diseases are considered to be the most serious.

Hence multi-pronged strategy needs to be adopted to manage the vectors and virus diseases. Some of the important components of such a strategy should involve selection of healthy seed, cultural practices, biological measures, resistant varieties and use of chemicals. 


\section{Healthy seed}

Management of virus diseases starts with obtaining healthy seed, cutting or plants. Care should be taken to obtain only certified seed, i.e. seed obtained from the plants which have been inspected during growing season and found free of certain diseases. With heat treatment virus free stock can be prepared, i.e. growing plants at high temperature for a weeks or even months. The production of virus free stocks can also be achieved by taking advantage of the fact that some plants grow and elongate faster than the virus can occupy the new tissue. Therefore, the virus can be eliminated by using meristem or tip cultured plants. Virus free stock is tested by indexing (growing a part of the culturing or plant in a pot or greenhouse and recording its condition with respect to disease symptoms), bioassays and/or serological assays.

\section{Host plant resistance}

Growing resistant and tolerant verities is another effective way of managing vectors and vector-transmitted diseases. The efficacy of plant resistance to vector depends on the means of resistance and the mode of transmission. Resistance that prevents feeding or repels the insects can prevent transmission of pathogens spread by feeding. If the resistance merely prevents or slows population growth, it cannot prevent primary spread. It can, however, have some effect on secondary spread. Resistance to the pathogen may be the only means of management in some cases. An example is sugarcane mosaic virus. Sugarcane is propagated vegetatively, so the virus is propagated with the crop. Once planted, a crop remains in the same field for several years of production, and planting is staggered throughout the production area. Thus, even if clean planting stock could be found, there is no possibility for an area wide crop free and virus-free period. The virus is transmitted by transient winged aphids, including species that do not necessarily colonize the sugarcane crop, so pesticide application is not effective. Fortunately, there has been success with mosaic resistant cultivars.

\section{Cultural Control}

Several cultural practices have proved to be helpful in reducing the incidence of vectors and vector borne diseases. Many of the effective management practices for diseases caused by vectored plant pathogens involve some sort of cultural control such as adjusted planting date, pruning, roguing and removal of volunteer crop plants and other non-crop reservoir hosts of vectors or pathogens. Control of volunteer crop plants may limit or eliminate primary inoculum for newly planted crops. Volunteer potatoes are important sources of virus inoculum in Idaho potato seed production areas. Similarly, volunteer grain can be an important reservoir for aphids and barley yellow dwarf at planting time for winter wheat.

The volunteer wheat provides a 'green bridge' for the viruses and their vectors between harvest of one crop and emergence of the next one (Halbert, 2011). Other cultural control measures include elimination of weed hosts of vectors or pathogens, use of reflective mulches and paints to repel vectors, and various protective row covers. Adjusting planting dates can minimize crop exposure to vectored pathogens. Intercropping with a barrier crop has provided encouraging results to reduce the incidence of several diseases. e.g. the incidence of yellow vein mosaic of okra is reduced by intercropping with soybean. Similarly, intercropping of tomato with coriander reduces the incidence of tomato leaf curl virus in tomato. Plant spacing such as close spacing reduces the incidence of French bean crinkle stunt disease. 
Manipulation in planting dates is another way of reducing the disease incidence. Roguing also help in the removal of the source of disease causing organism. Removal of weeds and alternate hosts of viruses and vectors helps to reduce the incidence of diseases.

\section{Biological control}

Biological control is also one of the most important tools for the management of vectored pathogens. Sometimes, the presence of natural enemies evokes scatter responses in vector prey. This can actually cause an increase in pathogen transmission. Biological control in simpler island ecosystems may have a better chance to work than in more complex settings. For example, the introduction of psyllid parasitoids into Reunion Island dramatically reduced the transmission of the bacteria that cause citrus greening disease. However, the same parasitoids are present in Viet Nam, and citrus greening disease is a major limiting factor in citrus production there. Sometimes disruption of these may increase the transmission of a plant pathogen if the existing biological control does not work efficiently.

Increased spraying for late blight in potatoes was linked to a major increase in numbers of green peach aphids. Evidently, populations had been controlled by an aphid pathogenic fungus that was killed by the fungicide applications for late blight. The result was increase in incidence of potato leafroll virus, transmitted by the aphids (Halbert, 2011).

\section{Biopesticides}

The use of biopestcides such microbial and plant extracts is an ecofriendly approach to manage the vectors and vectors borne diseases. Several neem based formulations have provided effective control of $B$. tabaci on cotton.

\section{Chemical control}

The control of insect vectors by application of insecticides appears to be a difficult task as few survivors would be able to transmit the disease. The timely application of insecticides restricts the spread of the disease by reducing the vector population. Several systemic and non-systemic insecticides have been reported to control the insect vectors.

\section{References}

Agrios, G.N. (1997). Plant pathology (4 ${ }^{\text {th }}$ edn.). Academics Press, San Diego, California.

Alma, A., Tedeschi, R., Lessio, F., Picciau, L., Gonella, E. and Ferracini, C. (2015). Insect vectors of plant pathogenic Mollicutes in the Euro-Mediterranean region. Phytopathogenic Mollicutes 5(2): 53-73.

Anderson, B.J., Boyce, P.M. and Blanchard, C.L. (1995). RNA 4 sequences from cucumber mosaic virus subgroups I and II. Gene 161:293-294.

Beanland, L., Hoy, C.W., Miller, S.A. and Nault, L.R. (2000). Influence of aster yellows phytoplasmas on the fitness of aster leafhopper (Homoptera: Cicadellidae). Ann. of Ent. Soc. America 93: 271-276.

Borth, W.B., Fukuda, S.K., Hamasaki, R.T., $\mathrm{Hu}$, J.S. and Almeida, R.P.P. (2006). Detection, characterization and transmission of X-disease Phytoplasm by the vector Colladonus montanus to Arabidopsis thaliana, a new experimental host plant. Pl. Dis. 89: 1121-1124.

Brown J.K. and Czosnek H. (2002). Whitefly transmission of plant viruses. In: Plumb RT, editor. Advanced in Botanical Research. Plant Virus Vector Interactions. New York: Academic Press. Vol. 36. 65-100. 
Brown J.K., Frolich D.R. and Rosell R.C. (1995). The sweet-potato or silverleaf whiteflies - Biotypes of Bemisia tabaci or a species complex. Ann. Rev. Entomol. 40: 511-534.

Chen, B., and Francki, R.I.B. (1990). Cucumovirus transmission by the aphid Myzus persicae is determined solely by the viral coat protein. J. Gen. Virol. 71:939-944.

Dalton, R. (2006). Whitefly infestations: The Christmas Invasion. Nature 443: 898900.

DeBarro, P.J., Liu, S.S., Boykin, L.M. and Dinsdale, A.B. (2011). Bemisia tabaci: a statement of species status. Ann. Rev. Entomol. 56: 1-19.

Dollet, M. (2001). Phloem-restricted trypanosomatids form a clearly characterized monophyletic group among trypanosomatids isolated from plants. Int. J. Parasitol. 31, 459-467.

Donaldson, J.R. and Gratton, C. (2007). Antagonistic effects of soybean viruses on soybean aphid performance. Environ. Entomol. 36: 918-925.

Drake, C.S., Gary, L.H., Frederick, E., Gildow, K.M.H. and Roy, F. (2005). Plant Virus HC-Pro Is a Determinant of Eriophyid Mite Transmission. $J$. Virology 79(14): 9054-9061.

Du, Z.Q., Li, L., Liu, L., Wang, X.F. and Zhou, G. (2007). Evaluation of aphid transmission abilities and vector transmission phenotypes of barley yellow dwarf viruses in china. $J . P l$. Path. 89(2): 251-259.

Fereres, A. and Moreno, A. (2009). Behavioural aspects influencing plant virus transmission by homopteran insects. Virus Res. 141: 158-168.

Fereres, A., Lister, R.M., Araya, J.E. and Foster, J.E. (1989). Development and reproduction of the English grain aphid (Homoptera, Aphididae) on wheat cultivars infected with Barley yellow dwarf virus. Environ. Entomol. 18: 388393.

Forbes, A.R. (1969). The stylets of the green peach aphid, Myzus persicae (Homoptera: Aphididae). Can. Entomol 101: 31-41.

Gamliel, A., Freeman, E.S., Sztejnberg, A., Maymon, M., Ochoa, R., Belausov, E. and Palevsky, E. (2009). Interaction of the mite Aceria mangiferae with Fusarium mangiferae, the causal agent of mango malformation disease. Phytopathology 99:152-159.

Gillot, C. (2005). Entomology. Springer, Dordrecht. The Netherland.

Gray, M.S. and Gildow, F.E. (2003). Luteovirus-aphid interactions. Ann. Rev. Phytopathology 41: 539-566.

Halbert, S.E. (2011). Management of insectvectored pathogens of plants. Florida Department of Agriculture and Consumer Services, Division of Plant Industry Gainesville, Florida, USA. 1-5 pp.

Hanboonsong, Y., Choosai, C., Panyim, S. and Danmark, S. (2002). Transovarial transmission of sugarcane whitefly leaf transmission in insect vector Matsumuratettix hieroglyphics (Matsumura). Insect Mol. Biol. 11: 97103.

Hogenhout, S.A., Ammar, E.D., Whitfield, A.E. and Redinbaugh, M.G. (2008). Insect vector interactions with persistently transmitted viruses. Ann. Rev. Phytopath. 46: 327-359.

Hsu, H.T., Barzuna, L., Hsu, Y.H., Bliss, W. and Perry, K.L. (2000). Identification and subgrouping of Cucumber mosaic virus with mouse monoclonal antibodies. Phytopathology 90: 615620.

Ingwell, L.L., Eigenbrode, S.D. and BosquePerez, N.A. (2012). Plant viruses alter insect behavior to enhance their spread. Sci. Rep. 2: 578. 
Jiu, M., Zhou, X.P., Tong, L., Xu. J. and Yang, X. (2007). Vector-virus mutualism accelerates population increase of an invasive whitefly. PLOS ONE 2(1): e182. doi: 10.1371/journal.pone.0000182.

Kant, M.R., Sabelis, M.W., Haring, M.A. and Schuurink, R.C. (2008). Intraspecific variation in a generalist herbivore accounts for differential induction and impact of host plant defences. Proc. Royal Soc. B 275: 443-452.

Liu, S.S., Colvin, J. and DeBarro, P.J. (2012). Species concepts as applied to the whitefly Bemisia tabaci systematics: How many species are there? J. Integr. Agric. 11(2): 176-186.

Luan, J.B., Yao, D.M., Zhang, T., Walling, L.L. and Yang, M. (2012). Suppression of terpenoid synthesis in plants by a virus promotes its mutualism with vectors. Ecol. Lett. 16(2): 390-398.

Mirzaie, A., Esmailzadeh, H.S.A., Jafari, N.A. and Rahimian, H. (2006). Molecular characterization and potential insect vector a phytoplasma associated with garden beet witches' broom in Yazd, Iran. J. Phytopath. 155(4): 198203.

Moreno-Delafuente, A., Garzo, E., Moreno, A. and Fereres, A. (2013). A Plant Virus Manipulates the Behavior of Its Whitefly Vector to Enhance Its Transmission Efficiency and Spread. PLOS ONE 8(4): e61543. doi:10.1371/journal.pone.0061543.

Munyaneza, J.E., Crosslin, J.M. and Upton, J.E. (2007). Beet leafhopper (Hemiptera: cicadellidae) transmits the Columbia basin potato purple top phytoplasma to potatoes, beets and weeds. J. Econ. Ent. 99(2): 268-272.

Nault, L.R. (1997). Arthropod transmission of plant viruses: A new synthesis. Ann. Entomol. Soc. Am. 90: 521-541.
Navas-Castillo, J., Fiallo-Olive, E. and Sánchez-Campos, S. (2011). Emerging virus diseases transmitted by whiteflies. Ann. Rev. Phytopathol. 49: 219-48.

Ng, J.C.K. and Falk, B.W. (2006). Virusvector interactions mediating nonpersistent and semipersistent transmission of plant viruses. Ann. Rev. Phytopathol. 44: 183-212.

Palukaitis, P., Roossinck, M.J., Dietzgen, R.G. and Francki, R.I.B. (1992). Cucumber mosaic virus. Adv. Virus Res. 41: 281-348.

Perry, K.L., Zhang, L., and Palukaitis, P. (1998). Amino acid changes in the coat protein of cucumber mosaic virus differentially affect transmission by the aphids Myzus persicae and Aphis gossypii. Virology 242: 204-210.

Polston, J.E., and Capobianco, H. (2013). Transmitting plant viruses using whiteflies. J. Vis. Exp. 8(81): e4332. doi: $10.3791 / 4332$.

Pusag, J.C.A., Jahan, S.M, H., Kwan-Suk, L., Sukchan, L. and Kyeon-Yeoll, L. (2012). Upregulation of temperature susceptibility in Bemisia tabaci upon acquisition of Tomato Yellow Leaf Curl Virus (TYLCV). J. Insect Physiol. http://dx.doi.org/

10.1016/j.jinsphys.i.07.008.

Roossinck, M.J. (2002). Evolutionary history of Cucumber mosaic virus deduced by phylogenetic analyses. J. Virol. 76: 3382-3387.

Rosen, R., Kanakala, S., Kliot, A., Pakkianathan, B.C., Farich, B.A., Magal, N.S., Elimelech, M., Kontsedalov, S., Lebedev, G., Cilia, M. and Ghanim, M. (2015). Persistent, circulative transmission ofr begomoviruses by whitefly vectors. Curr. Opinion Virol. 15:1-8.

Rubinstein, G. and Czosnek, H. (1997). Longterm association of tomato yellow leaf curl virus with its whitefly vector 
Bemisia tabaci: effect on the insect transmission capacity, longevity and fecundity. J. Gen. Virol. 78: 2683-2689.

Salehi, M., Izadpanah, K. and Nejat, N. (2006). A new phytoplasma infecting lettuce in Iran. Pl. Dis. 90(2): 247.

Sarwar, M. (2014). Some Insect Pests (Arthropoda: Insecta) of Summer Vegetables, Their Identification, Occurrence, Damage and Adoption of Management Practices. Int. J. Sustainable Agric. Res. 1(4): 108-117.

Stafford, C.A., Walker, G.P. and Ullman, D.E. (2011). Infection with a plant virus modifies vector feeding behavior. www.pnas.org/cgi/doi/10.1073/pnas.11 00773108.

Sun, D.B., Xu, J., Luan, J.B. and Liu, S.S. (2011). Reproductive incompatibility between the $\mathrm{B}$ and $\mathrm{Q}$ biotypes of the whitefly Bemisia tabaci in China: genetic and behavioural evidence. Bull. Entomol. Res. 101: 211-220.

Tedeschi, R. and Alma, A. (2006). Fieberiella florii (Homoptera: Auchenorrhyncha) as a vector of Candidatus hytoplasma mali. Pl. Dis. 90(3): 284-290.

Thind, B. S. (2012). Phytopathogenic prokaryotes and plant diseases Pp 327476. Scientific Publishers, India.

Uzest, M., Gargani, D., Drucker, M., Hebrard, E., Garzo, E., Candresse, T. (2007). A protein key to plant virus transmission at the tip of the insect vector stylet. Proc. Natl. Acad. Sci. U.S.A. 104, 17959-17964.

Wang, J., Bing, X.L., Li, M., Ye, G.Y. and Liu, S.S. (2012). Infection of tobacco plants by a begomovirus improves nutritional assimilation by a whitefly. Entomol. Exp. Appl. 144: 191-201.

Weintraub, P.G. (2007). Insect vectors of phytoplasmas and their control-an update. Bull. Insectology 60(2): 169173.

Weintraub, P.G. and Beanland, L. (2006). Insect vectors of phytoplasmas. Ann. Rev. 51: 91-111.

Whipple, O.C., and Walker, J.C. (1941). Strains of cucumber mosaic virus pathogenic on bean and pea. J. Agric. Res. 62: 27-60.

Whitfield, A.E., Falk, B.W., and Rotenberg, D. (2015). Insect vector-mediated transmission of plant viruses. Virology 47: 278-289.

Zhang, T., Luan, J., Qi, J., Huang, C. and Li, M. (2012). Begomovirus-whitefly mutualism is achieved through repression of plant defences by a virus pathogenicity factor. Mol. Ecol. 21(5): 1294-1304.

\section{How to cite this article:}

Ravinder Singh Chandi, Sanjeev Kumar Kataria and Jaswinder Kaur. 2018. Arthropods as Vector of Plant Pathogens Viz-a-Viz Their Management. Int.J.Curr.Microbiol.App.Sci. 7(08): 4006-4023. doi: https://doi.org/10.20546/ijcmas.2018.708.415 